\title{
Spinal Cord Injury in Forty-four Patients with Cervical Spondylosis*
}

\author{
Dominic Foo, M.D.
}

Spinal Cord Injury and Neurology Services, West Roxbury Veterans Administration Medical Center and Department of Neurology, Harvard Medical School, Boston, Massachusetts, U.S.A.

\section{Summary}

Within a 12-year period, $44\left(9 \cdot 4^{\circ}{ }_{0}\right)$ of 466 patients had spinal cord injury complicating cervical spondylosis. A history of alcoholic use preceding the accident was obtained in $12\left(54 \cdot 5^{\circ}\right)$ of 22 patients whose cord injury was due to a minor fall. The initial myelopathy was complete in 10 patients and incomplete in 34. Although neurological recovery was seen in the majority of the patients with incomplete cord lesion, complete recovery was unusual and most of the patients were partly or completely wheelchair dependent. No patient developed acute neurological deterioration after injury but seven expired. The mortality rate was much higher in the patients whose initial cord lesion was complete $\left(50^{\circ}{ }_{0}\right.$ or $\left.5 / 10\right)$ than in those with incomplete myelopathy $\left(5 \cdot 9^{\circ}{ }_{0}\right.$ or $\left.2 / 34\right)$. There was no delayed neurological deterioration due to progressive spondylosis of the spine but three patients developed post-traumatic syringomyelia several months to several years after the injury.

Key words: Cervical spondylosis; Spinal cord injury; Spinal fracture; Syringomyelia; Mortality.

\section{Introduction}

There have been many publications in the literature on the association between cervical spondylosis and spinal cord injury with regard to the cause and mechanism of the injury, clinical presentation, radiological features, and autopsy findings (Hardy, 1977; Hughes and Brownell, 1963; Schneider et al., 1954; Symonds, 1953; Young et al., 1977-78). However, there have been very few reports on the incidence of traumatic myelopathy complicating cervical spondylosis in a Spinal Cord Injury Centre and on the study and follow-up of a large number

* This paper was presented in part at the Annual Meeting of the American Spinal Injury Association, March 26-28, 1984, Houston, Texas, U.S.A., and in part at the Annual Meeting of the American Paraplegia Society, September 4-6, 1985, Las Vegas, Nevada, U.S.A. Requests for Reprints to Dominic Foo, M.D., Veterans Administration Medical Center, 1400 VFW Parkway, West Roxbury, MA 02132, U.S.A. 
of these patients. The purpose of this paper is to evaluate the incidence of spinal cord injury in patients with cervical spondylosis in this Spinal Centre, to identify other factors that may predispose these patients to injury, to assess their recovery and mortality, and to show that delayed onset of progressive myelopathy is usually the result of the formation of a syrinx rather than the result of cord compression by progressive spondylosis.

\section{Patients and methods}

From 1 May 1973 to 31 May 1985, 455 male and 21 female patients with acute spinal cord injury were admitted to the Spinal Cord Injury Centre in West Roxbury Veterans Administration Medical Centre, excluding those with spinal fracture without myelopathy or those with atraumatic myelopathy; their ages ranged from 14 to 84 years (mean, 34 years) and most of them were admitted within 6 weeks of their trauma. Post-traumatic myelopathy associated with cervical spondylosis, which was defined by the presence of radiological evidence of osteophyte formation causing narrowing of the spinal canal or intervertebral foramina, was seen in 44 male subjects. Patients with only slight degenerative changes of the spine were not included in this study. The myelopathy was sensory and motor complete in 10 patients, sensory incomplete but motor complete in four, sensory complete but motor incomplete in four, and sensory and motor incomplete in 26. Many of these patients had been followed by us at least once a year since their injury. The follow-up period of 37 patients who survived their cord injury ranged from 4 months to 10 years (mean, 3 years), postinjury. The medical records of their first and subsequent admissions were reviewed; a few patients were personally contacted by phone to update their current condition. A patient was considered to have recovery or improvement of his deficits if he showed more than slight sensory or motor return below the level of his spinal injury. Patients who died after they were discharged from the hospital after completing their rehabilitation were not included in the calculation of the mortality rate of the patients whose death was directly related to their cord injury.

\section{Results}

The 44 patients studied were aged from 50 to 84 years (mean, 65 years) at the time of their injury. They were admitted within 6 weeks of injury, with the exception of three patients. Twenty-two patients were admitted within 7 days postinjury. The causes of the trauma were as follows: 22 patients had a minor fall; 15 were involved in an automobile accident; three fell from a height of 8 to 30 feet; two had a bicycle accident; and one was hit on the head by a broken chimney. The cause of the accident could not be found in the remaining patient who was lost to follow-up after his first hospitalisation. A history of alcoholic use before the accident was obtained in 12 of 22 patients whose cord injury was due to a minor fall, either from the patient himself or indirectly from the family; the blood alcohol level was obtained in two patients and it was 174 and $345 \mathrm{mg} / \mathrm{dl}$, respectively. There was no history of the use of alcohol in the other 22 patients who had automobile or other accidents. Cervical fracture and/or subluxation was observed in 24 patients. Two patients had unilateral facet dis- 
location with fracture and two had unilateral facet dislocation without fracture. Ligamentous damage only, evidenced by the presence of subluxation or widening of the anterior intervertebral disc without fracture, was seen in 11 patients. There was no radiological evidence of bony or ligamentous injury of the spine in the remaining five patients even with their neck in slight flexion or extension positions. Cervical myelograms in 10 patients showed evidence of cord swelling at the fractured site, in the absence of a prolapsed disc or loose bone fragment within the spinal canal. Another patient had myelographic evidence of a large extradural defect which was found at operation to be an epidural haematoma. A patient had wiring of the $\mathrm{C} 2$ and $\mathrm{C} 3$ vertebrate because the halo vest failed to give a satisfactory alignment at the site of subluxation and another had anterior cervical decompression 1 week post injury which was followed 3 weeks later by posterior laminectomy. There was partial neurological recovery in these three patients post-operatively. Forty-one patients were treated conservatively. In general, the patients who had spinal fracture or dislocation had skull traction for a period of 8 to 12 weeks after the dislocation was reduced; in some of the patients with grossly incomplete cord lesion, the fractured site was immobilised with a halo vest for 2 to 3 months after they had skull traction for 1 to 2 weeks. The other patients with no bony lesion or with a stable spine in spite of ligamentous damage were treated with a collar. A tapering course of parenteral Decadron was given in most of the patients for 1 to 2 weeks post injury after a loading dose of 10 to $20 \mathrm{mg}$.

The neurological progress of the 41 patients who were treated conservatively is summarised in Table 1 . None of the patients had acute neurological deterioration secondary to an unstable spine. Medical complications occurred in four patients who expired within 3 months of their trauma. Another three patients who had a protracted course in the hospital because of recurrent pulmonary or cardiac problems died 11 months, 18 months, and 20 months postinjury, respectively. In these seven patients who expired, the initial myelopathy was complete in five and incomplete in two. The mortality rate was $50^{\circ}{ }_{0}(5 / 10)$ in the patients whose post-traumatic myelopathy was complete versus $5.9^{\circ}{ }_{0}(2 / 34)$ in those with incomplete cord lesion. Twenty-seven patients were able to return home after discharge but 10 remained in a chronic care facility, including nursing homes. The ambulatory state in 37 patients who survived their spinal injury is summarised in Table 2. Post-traumatic syringomyelia was found in three patients 4 months, 5 years, and 6 years after their trauma, respectively. However, none of the patients developed delayed neurological deterioration secondary to cord compression by osteophytes.

Table 1 Neurological recovery in 41 patients with cervical spondylosis and spinal cord injury treated conservatively

\begin{tabular}{lcc} 
& \multicolumn{2}{c}{ Spinal Cord Injury } \\
\cline { 2 - 3 } \multicolumn{1}{c}{ Neurological Recovery } & Complete & Incomplete \\
\hline Complete & 0 & 1 \\
Partial & 2 & 25 \\
None & 7 & 6 \\
Total & 9 & 32 \\
\hline
\end{tabular}


Table 2 Ambulatory status in 37 patients with cervical spondylosis who survived their spinal cord injury

\begin{tabular}{lcc}
\hline & \multicolumn{2}{c}{ Spinal Cord Injury } \\
\cline { 2 - 3 } Ambulatory status & Complete & Incomplete \\
\hline $\begin{array}{c}\text { Independent Ambulation } \\
\text { Without Support }\end{array}$ & 0 & 3 \\
$\begin{array}{c}\text { Walking with a Cane } \\
\text { or Crutch }\end{array}$ & 0 & 7 \\
$\begin{array}{c}\text { Partially Wheelchair } \\
\text { Dependent }\end{array}$ & 0 & 9 \\
$\begin{array}{c}\text { Completely Wheelchair } \\
\text { Dependent }\end{array}$ & 5 & 13 \\
\begin{tabular}{c} 
Total \\
\hline
\end{tabular} & 5 & 32 \\
\hline
\end{tabular}

\section{Discussion}

Cervical spondylosis was seen in 107 patients with spinal cord trauma among 384 successive neck injuries admitted to the Sheffield Spinal Injuries Unit (Hardy, 1977). In this study, the incidence of traumatic myelopathy complicating cervical spondylosis was $9 \cdot 4^{\circ}{ }_{0}(44 / 466)$ over a period of 12 years. Similar to the patients with ankylosing spondylitis (Foo et al., 1985), minor fall preceded by alcoholic consumption was a common cause of spinal cord injury in our patients with cervical spondylosis. However, it was not a contributory factor when the myelopathy was secondary to automobile or other accidents. While all the patients of Hardy (1977) had no bony damage, about $60^{\circ}{ }_{0}(26 / 44)$ of the patients studicd had vertebral fracture but facet dislocation was relatively uncommon $\left(9^{\circ}{ }_{0}\right.$ or $4 / 44)$. Ligamentous injury alone in the absence of spinal fracture was noted in $25^{\circ}{ }_{0}(11 / 44)$ of our patients and about $11^{\circ}{ }_{0}$ (5/44) had no evidence of fracturedisplacement. In a patient with extensive degenerative changes of the spine, it is sometimes difficult to identify by radiographs a mild compression fracture, a minor subluxation, or slight separation of the anterior intervertebral disc space. In 10 of our patients a spinal lesion was missed by the outside referring physician, but was found to be present when their cervical radiographs were repeated in a position of slight extension, or when, in addition tomograms were performed. The choice of treatment depends on the presence or absence of vertebral injury. If there is no bony damage, no special treatment is needed apart from the use of a supporting collar (Hardy, 1977). Immobilisation of the cervical spine with skull traction is indicated if there is a fracture, unstable subluxation, or dislocation.

The prognosis for recovery is better if the myelopathy is incomplete and useful neurological return is rare following a complete spinal cord injury (Hardy and Rossier, 1975). As only three of our patients had operative treatment, this study demonstrated the natural course of the patients with cervical spondylosis and spinal cord injury under conservative therapy. The iniitial cord lesion in most of our patients was incomplete, similar to the patients of Hardy (1977) and Young et al. (1977-78). Although neurological recovery was seen in the majority of the patients with incomplete cord injury, complete recovery was very rare and most of these patients were partly or completely wheelchair dependent (Tables 1 and 2). A central cord syndrome commonly occurs in patients with 
cervical spondylosis after a hyperextension injury (Schneider et al., 1954). Some of our patients who had proprioceptive loss in their legs did not have the arm swing necessary to maintain their equilibrium in walking and the others did not have enough motor return in the upper limbs to grip crutches or a walker although their legs were strong enough to carry them in the upright position.

In contrast to the patients with ankylosing spondylitis (Foo et al., 1985), none of our patients with cervical spondylosis had evidence of acute neurological deterioration after their injury. This is because fracture of the spondylotic spine is usually incomplete and stable (Young et al., 1977-78). Delayed onset of progressive myelopathy was noted in three patients several months to several years postinjury; in two patients, the increased neurological deficits were initially assumed to be secondary to cord compression by osteophytes. Subsequent investigation by gas myelography or spinal computerised tomography showed the presence of a syrinx. With the exception of one patient who had metastic spinal epidural carcinoma, post-traumatic syringomyelia has been the only cause of delayed onset of progressive myelopathy in all our patients with spinal cord injury. (Rossier et al., 1985). This study also showed a very high mortality rate in the patients whose initial myelopathy was complete $\left(50^{\circ}{ }_{0}\right.$ or $\left.5 / 10\right)$, in comparison to those with incomplete cord lesion $\left(5.9^{\circ}{ }_{0}\right.$ or $\left.2 / 34\right)$. Ducker et al. (1979) have demonstrated that a patient with a complete cervical injury has the highest mortality rate because of the greater incidence of respiratory problems, cardiovascular instability, and the sequelae of more pronounced immobility, namely, pressure sores, deep venous thrombosis, pulmonary emboli, and sepsis.

\section{Résumé}

En une période de 12 ans, chez 44 malades, soit $9 \cdot 4^{\prime \prime}{ }_{(1)}$, d'un groupe de 466 , souffrant d'un traumatisme de la moelle, l'atteinte a été une complication de la spondylose cervicale. Chez 12 malades, soit $54.5^{\circ}$ ", parmi 22 dont l'atteinte de la moelle a été précipitée par une chute mineure, l'anamnèse a revélé une consommation d'alcool avant l'accident. Chez 10 malades la myélopathie initiale était complète alors que chez 34 elle était incomplète. Bien que la majorité des malades avec lésion incomplète ont présenté une amélioration neurologique, la récupération totale a été exceptionelle et la plupart des malades ont demeuré partiellement ou totalement dépendant des fauteuils roulants. Aucun malade n'a développé de détérioration neurologique aiguë à la suite du traumatisme, mais 7 malades sont morts. Le taux de mortalité de $50^{\prime \prime}$ ", soit 5 surlo, parmi les malades à atteinte initiale de la moelle complète a été beaucoup plus élevé que celui des malades avec atteinte initiale incomplète, $5 \cdot 9^{\prime \prime}$ "soit 2 sur 34 . Aucune détérioration neurologique tardive secondaire à la progression de la spondylose cervicale n'a été observée. Trois malades ont développé une syringomyélie posttraumatique plusieurs mois à plusieurs années suivant l'accident.

\section{Zusammenfassung}

Innerhalb eines Zeitraumes von 12 Jahren zeigten $44\left(9 \cdot 4^{\prime \prime}\right.$ ") von 466 Patienten mit Rückenmarksverletzungen als Komplikation eine zervikale Spondylosis. Von 22 Patienten, deren Rūckenmarksverletzung durch einen leichten Sturz verusacht wurde, konnte bei $12\left(544^{\prime \prime}\right.$ ") ein Alkoholkonsum vor dem Unfall nachgewiesen werden. Die anfangliche Querschnittslähmung war bei 10 Patienten komplett, bei 34 partiell. Obwohl bei der Mehrheit der Patienten mit partieller Querschnittslähmung eine neurologische Verbesserung gesehen werden konnte, war eine vollständige Heilung die Ausnahme und die meisten Patienten blieben teilweise oder ganze Rollstuhl abhängig. Kein Patient zeigte eine akute neurologische Verschlechterung nach der Vereltzung, 7 Patienten verstarben jedoch. Die Mortalitt war bei Patienten mit von Anfang an kompletter Querschnittslämung wesentlich größer $\left(50^{\prime \prime}\right.$ " oder $\left.5 / 10\right)$ als bei jenen mit partieller Querschnittslähmung $\left(5 \cdot 9^{\prime \prime}\right.$ "oder $\left.2 / 34\right)$. Es wurde keine verzögerte neurologische Verschlechterung als Folge der progressiven Spondylosis festgestellt, 3 Patienten entwickelten allerdings eine posttraumatische Syringomyelie mehrere Monate bis mehrere Jahre nach der Verletzung. 


\section{References}

Ducker TB, Russo GL, Bellegarrique R, et al. 1979 Complete sensorimotor paralysis after cord injury: mortality, recovery, and therapeutic implications. Journal of Trauma 19:837-840. Foo D, Sarkarati M, Marcelino V 1985 Cervical spinal cord injury complicating ankylosing spondylitis. Paraplegia 23:358-363.

HARDY AG 1977 Cervical spinal cord injury without bony injury. Paraplegia 14:296-305.

HARDy AG, Rossier AB 1975 Spinal cord injuries: orthopaedic and neurological aspects. Georg Thieme, Stuttgart.

Hughes JT, Brownell B 1963 Spinal-cord damage from hyperextension injury in cervical spondylosis. Lancet 1:687-690.

Rossier AB, Foo D, Shillito J, et al. 1985 Post-traumatic cervical syringomyelia. Incidence, clinical presentation, electrophysiological studies, syrinx protein and results of conservative and operative treatment. Brain 108: 439-461.

Schneider RC, Cherry G, Pantek H 1954 The syndrome of acute central cervical spinal cord injury. Journal of Neurosurgery 11:546-577.

Symonds C 1953 The interrelation of trauma and cervical spondylosis in compression of the cervical cord. Lancet 1:451-454.

Young JS, Cheshire DJE, Pierce JA, Vivian JM 1977-78 Cervical ankylosis with acute spinal cord injury. Paraplegia 15:133-146. 